\title{
Collaborative Experiential Learning Process for Enhancing Digital Entrepreneurship
}

\author{
Suvanna Trongtorsak ${ }^{1}$, Kobkiat Saraubon ${ }^{1} \&$ Prachyanun Nilsook $^{1}$ \\ ${ }^{1}$ Division of Information and Communication Technology for Education, Faculty of Technical Education, King \\ Mongkut's University of Technology North Bangkok, Bangkok, Thailand
}

Correspondence: Suvanna Trongtorsak, Division of Information and Communication Technology for Education, Faculty of Technical Education, King Mongkut's University of Technology North Bangkok, Bangkok, Thailand. Tel: 66-879-715-583. E-mail: s5902052910096@email.kmutnb.ac.th

Received: November 23, 2020

Accepted: January 6, $2021 \quad$ Online Published: January 27, 2021

doi:10.5539/hes.v11n1p137

URL: https://doi.org/10.5539/hes.v11n1p137

\begin{abstract}
The objectives of this research were as follows: 1) to develop the collaborative experiential learning process for enhancing digital entrepreneurship, and 2) to carry out a suitability assessment of this process. In this study, the researcher performed analysis and synthesis involving the process of experiential learning, collaborative learning, and digital entrepreneurship learning, and 21 experts with three years' experience in a related field perform a suitability assessment of the collaborative experiential learning process. The findings were as follows:

1. The collaborative experiential learning process for enhancing digital entrepreneurship is composed of five steps, 15 processes as follows; 1) inspiration, 2) exploration, 3) engagement, 4) presentation and 5) utilization.

2. The suitability assessment results of the collaborative experiential learning process for enhancing digital entrepreneurship assessed by experts; the overall result is at the highest level.
\end{abstract}

Keywords: experiential learning, collaborative learning, collaborative experiential learning, digital entrepreneur learning.

\section{Introduction}

\subsection{Introduce the Problem}

It is predicted that the global economy will have significant change over significantly during the 21 st century and shift the industrial economy from manufacturing towards a knowledge-based industry and creative thinking economy. Besides, technology will bring about changes in the economic base affecting the physical location of workplaces and working patterns. The use of digital technology (Thanachawengsakul et al., 2019) is essential for moving forward and transforming the new digital economy and society. It means that people must adjust to technological change as it is an important aspect that can improve their lives (van Laar et al., 2018). The ability to understand and use technology and become digitally literate is important, particularly information skills, digital tool usage, and digital transformation. Therefore, digital fluency is a crucial skill for success in the 21 st century (Techakosit \& Nilsook, 2016).

Education is an essential tool for the social and economic growth of a country (Madani, 2019). Learning is a process that is a fundamental stage of adjustment for people and can offer management support in particular areas such as strategic planning for entrepreneurs, creative thinking, problem-solving, decision making, and leadership. Experiential learning is a process of developing knowledge and skills and enhancing value through best practice (Kang \& Chen, 2016). It allows students to connect what they learn and the real world leading to knowledge acquisition, understanding abstract concepts, and experiential learning methods that focus on improving students' practical experience (Shiralkar, 2016).

Collaboration is an essential $21^{\text {st }}$ century skill. It is not a new method of learning but is part of experiential learning developed over several years. Collaborative learning is an educational approach to teaching and learning that fulfills the real purpose of education. Many studies demonstrate the effectiveness of collaborative learning and how, unlike individual learning, it enables students to work in pairs or groups and actively interact by sharing their experience and knowledge (Kuandee et al., 2019). 
Due to technological advancement in the digital age, changes have occurred in the physical world, affecting business decisions and marketing. The integration of technology impacts all business areas with digital services accessible on intelligent systems (Kuandee et al., 2019), creating thousands of digital entrepreneurs. A digital entrepreneur refers to a new establishment, business, product, or service available on the internet and a new entrepreneur with a start-up business. Digital skills are essential to successful entrepreneurship, so organizations may want to identify and recruit an in-house technology expert to create business opportunities and achieve their goals (van Welsum, 2016). As entrepreneurs are essential to driving economic growth, students should be given education in entrepreneurship. During the past few years, information and communication technology has developed, resulting in computer dynamics in education that facilitate learning by providing students with new learning channels, content, and strategy. Successful development in this area can significantly contribute to higher education (Ruangvanich \& Nilsook, 2018), which is crucial to the collaborative experiential learning process for enhancing digital entrepreneurship.

\section{Literature Review}

\subsection{Experiential Learning}

The concept of experiential learning focuses on problem-solving skills and critical thinking, distinct from rote learning (Dewey, 1986). Knowledge creation through sharing experience or learning by doing is defined as a substantial learning experience (Kolb, 2014). Experiential learning is a fundamental process that provides opportunities for students to actively engage in acquiring skills and knowledge (Honey \& Mumford, 1992).

Experiential learning is not a new classroom concept but is a process of learning through experience, which is more effective than traditional learning, such as a lecture or reading (Kolb, 2014). It relates to the students' direct experience's meaning-making process without a facilitator's presence (Shiralkar, 2016). Students engage in experiential learning in activities followed by acquiring knowledge and skills, enhancing value through best practice (Kang \& Chen, 2016).

This type of experiential learning is aligned with the knowledge development process and refers to the way students-are stimulated and perceived and the concrete experience they develop from practical exercises. It is complex and relates to reflective observations and how people think about what they have done or experienced, the knowledge they gather from memory, and information, guidance, and advice from experts. Learning from observation and the utilization of knowledge is meaningful to students (Dewey, 1986). Students who engage in an experiential learning process using a systematic and continuous approach can obtain and apply knowledge from authentic learning experiences. The students learning experience is derived from the knowledge construction process by reflecting on what they are doing, whereas knowledge acquisition involves learning with understanding (Liu et al., 2019).

\subsection{Collaborative Learning}

Collaborative learning provides students with opportunities to participate in small-group activities by working towards a common goal, including analysis, exchanging ideas, and discussions. Each group member is responsible for their role, and after evaluation, feedback is given to each member and group to identify those who may need additional support (Laal et al., 2013) (Cooper \& Burford, 2010) (Panitz, 1999) (Koschmann et al., 1996) (Gerlach, 1994) (Johnson \& Johnson, 1986).

Collaboration has become a $21^{\text {st }}$ century trend due to society's increasing need to think and work together on critical concern issues, so the emphasis has shifted from individual effort to group work (Laal et al., 2013). Collaborative learning represents a significant shift away from the typical teacher-centered or lecture-centered approach in the classroom, as group members work alongside each other conversing and working towards the same goals or completing tasks. It helps construct knowledge through mutual interaction and support in everyday situations (Majid et al., 2013) and reflects how respectful interactions with others are managed. It also highlights group members' abilities and successes and their responsibilities and an appreciation of others' viewpoints. Collaborative learning is based upon consensus building through group members' unanimous consent (Laal \& Laal, 2012).

\subsection{Digital Entrepreneurship Learning}

Learning about entrepreneurship is a continuous process of knowledge development consisting of learning, sharing, grouping, and utilizing entrepreneurs' knowledge for effective business management and new challenges (Xiu-qing \& Li, 2013) (Politis, 2005).

Entrepreneurship is a thought process that leads to discoveries for individuals and businesses, including new business, strategic changes, obligations, organizational structures, the use of innovative technology, product 
development, a wide variety of markets, and new business alliances. During the past few decades, a theory of entrepreneurship has been developed based on research findings. The entrepreneurship process is highlighted in an investigation of the learning process and during the development of entrepreneurship. Learning is a social process and a perceptual process of knowledge. Entrepreneurship is a process of learning, and a theory of entrepreneurship requires a theory of learning. Entrepreneurial learning is a dynamic process that occurs during the entrepreneurial journey, and a continuous learning process allows entrepreneurs to develop and grow business. Moreover, some academics are interested in entrepreneurs' learning experience which is a fundamental part of continuous learning development for entrepreneurs (Secundo et al., 2017).

Digital entrepreneurs who have put their best creative thinking into practice and done well (Zhao \& Collier, 2016), leverage technology in novel ways to create and do business in the digital era. This also creates opportunities for others and has an impact on digital business in society. Digital entrepreneurship is 'a subcategory of entrepreneurship in which some or all of what would be physical in a traditional organization has been digitized. Thus, traditional entrepreneurs should make an effort to transform their existing products, services, and businesses into digital models' (Kraus et al., 2018).

\section{Research Objectives}

The objectives of this research are to:

3.1 Develop the Collaborative Experiential Learning Process for Enhancing Digital Entrepreneurship, and To

3.2 Carry out A Suitability Assessment of the Collaborative Experiential Learning Process for Enhancing Digital Entrepreneurship

\section{Research Methodology}

The research methodology has two phases, as follows

\subsection{Phase I: The Development of a Collaborative Experiential Learning Process for Enhancing Digital Entrepreneurship}

Studies of the experiential learning process, collaborative learning process, and digital entrepreneur learning process based upon the information gathered from documents, textbooks, academic journals, concepts, and theories of relevant research papers, including analysis and synthesis of the data using a content analysis approach.

Use the data obtained from the synthesis approach to developing the collaborative experiential learning process for enhancing digital entrepreneurship.

4.2 Phase II: A Suitability Assessment of the Collaborative Experiential Learning Process for Enhancing Digital Entrepreneurship

A questionnaire with five rating scales was employed as a data collection tool. Twenty-one experts with three years' experience in a related field performed the assessment (purposive sampling).

\section{Research Findings}

\subsection{Phase I: Study Results of the Collaborative Experiential Learning Process for Enhancing Digital} Entrepreneurship

\subsubsection{Synthesis Results of the Experiential Learning Process}

Experiential learning is a process of knowledge construction through experience where students are given opportunities to shape their experience followed by applying knowledge in real-world situations. Details are provided in Table 1 
Table 1. The Synthesis Results of Experiential Learning Process

\begin{tabular}{|c|c|c|c|c|c|c|c|c|}
\hline $\begin{array}{l}\text { The Experiential } \\
\text { Learning } \\
\text { Process Steps }\end{array}$ & $\begin{array}{l}\text { Institute for } \\
\text { Experiential } \\
\text { Learning } \\
(2016)\end{array}$ & $\begin{array}{l}\text { Haynes } \\
\text { (2007) }\end{array}$ & $\begin{array}{l}\text { Honey } \\
\text { and } \\
\text { Mumford } \\
\text { (1992) }\end{array}$ & $\begin{array}{l}\text { Kolb } \\
\text { (2014) }\end{array}$ & $\begin{array}{l}\text { Pfeiffer } \\
\& \\
\text { Jones } \\
(1983)\end{array}$ & $\begin{array}{l}\text { Ravensbergen } \\
\text { \& Schoneville } \\
(2013)\end{array}$ & $\begin{array}{l}\text { Ravensbergen } \\
\text { (2015) }\end{array}$ & $\begin{array}{l}\text { Synthesis } \\
\text { results } \\
\text { of the } \\
\text { Experiential } \\
\text { Learning } \\
\text { process }\end{array}$ \\
\hline Experience Creation & $\bullet$ & $\bullet$ & $\bullet$ & $\bullet$ & $\bullet$ & $\bullet$ & $\bullet$ & $\bullet$ \\
\hline Sharing Experience & & - & & - & - & - & - & - \\
\hline Review of & - & - & - & - & - & - & - & - \\
\hline Experiential & & & & & & & & \\
\hline Learning & & & & & & & & \\
\hline Summary of & & $\bullet$ & $\bullet$ & $\bullet$ & $\bullet$ & $\bullet$ & $\bullet$ & $\bullet$ \\
\hline Learning through & & & & & & & & \\
\hline Experience & & & & & & & & \\
\hline $\begin{array}{l}\text { Application of } \\
\text { Knowledge in } \\
\text { real-world }\end{array}$ & $\bullet$ & $\bullet$ & $\bullet$ & $\bullet$ & $\bullet$ & $\bullet$ & $\bullet$ & $\bullet$ \\
\hline Situations & & & & & & & & \\
\hline
\end{tabular}

According to the synthesis results shown in Table 1, the experiential learning process is composed of five steps:

1) Experience creation by stimulating, motivating, and encouraging students to learn by doing. Students engage in observations, deliberate decision-making, and making connections between what is taught in school and what is happening in the real world. This encourages them to develop their knowledge and skills.

2) Sharing experience by allowing students to share their individual experiences.

3) Review of experiential learning by enabling students to generate a thoughtful analysis of their learning experience. This reflects the students' learning experience outcomes and is connected with their beliefs, conceptions, and opinions. This type of learning process encourages students to express their opinions.

4) A summary of learning through experience, which relates to the cognitive constructivism of the students' knowledge gain from hands-on experience to make a set of rules, definitions, and algorithms for real-world application.

5) The application of knowledge in real-world situations helps students gain valuable insights into their skills' real-life applications.

\subsubsection{Synthesis results of the Collaborative Learning Process}

Collaborative learning allows students to participate in small-group activities by working towards common goals including analysis and exchanging ideas. The details are illustrated in Table 2.

Table 2. The Synthesis Results of Collaborative Learning Process

\begin{tabular}{lllllll}
\hline $\begin{array}{l}\text { The Collaborative } \\
\text { Process Steps }\end{array}$ & $\begin{array}{l}\text { Coleman \& } \\
\text { Levine (2008) }\end{array}$ & $\begin{array}{l}\text { Stacey } \\
(1999)\end{array}$ & $\begin{array}{l}\text { Gokhale } \\
(1995)\end{array}$ & $\begin{array}{l}\text { Gerlach } \\
(1994)\end{array}$ & $\begin{array}{l}\text { Reid } \\
\text { et al. (1989) }\end{array}$ & $\begin{array}{l}\text { Synthesis results } \\
\text { of the Collaborative } \\
\text { Learning process }\end{array}$ \\
\hline Stimulation & $\bullet$ & $\bullet$ & $\bullet$ & $\bullet$ & $\bullet$ & $\bullet$ \\
Exploration & $\bullet$ & & $\bullet$ & $\bullet$ & $\bullet$ & $\bullet$ \\
Knowledge sharing & $\bullet$ & $\bullet$ & $\bullet$ & $\bullet$ & & $\bullet$ \\
Adjustment & & $\bullet$ & $\bullet$ & & $\bullet$ & $\bullet$ \\
Presentation & $\bullet$ & $\bullet$ & $\bullet$ & $\bullet$ & $\bullet$ & $\bullet$ \\
\hline
\end{tabular}

According to the synthesis results in Table 2, the collaborative learning process is composed of five steps:

1) Stimulation: students search for useful information relevant to their project or assignment by interacting, sharing experiences, exchanging ideas, and collaborating among their teams. This strategy stimulates students' enthusiasm for learning.

2) Exploration: students explore and find concepts relating to their project or assignment by working on a collaborative project/assignment with a defined goal setting.

3) Knowledge sharing: group members have positive learning experiences where they share knowledge and experience among their teams. 
4) Adjustment: students adjust, modify, add ideas or concepts, and exchange information to align with the plans they collaborate on.

5) Presentation: Students from each group present the concepts, plans, and processes to other groups and exchange ideas and opinions.

\subsubsection{Synthesis Results of the Digital Entrepreneurship Learning Process}

The learning process for digital entrepreneurship. Details are provided in Table 3

Table 3. The Synthesis Results of the Digital Entrepreneurship Learning Process

\begin{tabular}{|c|c|c|c|c|}
\hline $\begin{array}{l}\text { The Digital } \\
\text { Entrepreneurship } \\
\text { Learning Process } \\
\text { Steps }\end{array}$ & $\begin{array}{l}\text { Lazada University } \\
\text { (2018); van Zyl (2018); } \\
\text { Xiu-qing \& Li (2013) }\end{array}$ & $\begin{array}{l}\text { Shopee Seller } \\
\text { Education Hub } \\
(2020) ; \\
\text { Holcomb (2016); } \\
\text { Secundo et al. } \\
\text { (2017) }\end{array}$ & $\begin{array}{l}\text { JD Central } \\
\text { Seller Help } \\
\text { Center } \\
\text { (2019); } \\
\text { Politis (2005) }\end{array}$ & $\begin{array}{l}\text { Synthesis results } \\
\text { of the Digital } \\
\text { Entrepreneurship } \\
\text { Learning process }\end{array}$ \\
\hline Stimulation & $\bullet$ & $\bullet$ & $\bullet$ & $\bullet$ \\
\hline Exploration & $\bullet$ & $\bullet$ & $\bullet$ & $\bullet$ \\
\hline Opportunity Assessment & $\bullet$ & $\bullet$ & $\bullet$ & $\bullet$ \\
\hline Business Implementation & $\bullet$ & $\bullet$ & $\bullet$ & $\bullet$ \\
\hline Product and Content & $\bullet$ & $\bullet$ & $\bullet$ & $\bullet$ \\
\hline Arrangement & & & & \\
\hline Inventory Management & $\bullet$ & $\bullet$ & $\bullet$ & $\bullet$ \\
\hline Purchase Order & $\bullet$ & $\bullet$ & $\bullet$ & $\bullet$ \\
\hline Management & & & & \\
\hline Delivery & $\bullet$ & $\bullet$ & $\bullet$ & $\bullet$ \\
\hline Financial Transaction & $\bullet$ & $\bullet$ & $\bullet$ & $\bullet$ \\
\hline Management & & & & \\
\hline Assessment & $\bullet$ & - & - & - \\
\hline Utilization & - & $\bullet$ & - & - \\
\hline
\end{tabular}

According to the synthesis results in Table 3, the learning process for digital entrepreneurship is composed of 11 steps:

1) Stimulation: this step involves the passing on of knowledge and developing an understanding of digital entrepreneurship and business processes to stimulate interest in business operations and digital entrepreneurship. Entrepreneurs must have some initial experience before starting a business.

2) Exploration: entrepreneurs have to find an interesting business they might want to start, followed by the generation of start-up ideas for the business, sources of financing, and the recruitment of employees to perform the duties set by organizations. The business plans must consist of information obtained during exploration.

3) Opportunity assessment: this step allows the entrepreneurs to see the overall outline of a business plan and the information contained therein, which is a valuable opportunity for assessing business start-ups.

4) Business implementation: the entrepreneur puts their products and services in the E-Marketplace, which is considered a start-up for digital entrepreneurs.

5) Product and content arrangement: entrepreneurs create content marketing plans and lists of products for the E-marketplace.

6) Inventory management: entrepreneurs perform inventory management by accommodating products in and out of the warehouse.

7) Purchase order management: this process begins when a customer makes a purchase, and an entrepreneur receives a purchase order. After payment is made, the next process is packing.

8) Delivery: entrepreneurs send out delivery items according to customers' purchase orders.

9) Financial transaction management: concerning the business operation in the E-marketplace, entrepreneurs are liable for charges arising from selling their products on a website.

10) Assessment: entrepreneurs perform an operational assessment by reviewing the information on the purchase order, the service, and the quality of the product. This step shows the overall result of business operations.

11) Utilization: entrepreneurs use the knowledge obtained from practical work for further business development.

According to studies of experiential learning process, collaborative learning process and learning process of 
digital entrepreneurship (as previously mentioned) can support further development of the collaborative experiential learning process for enhancing digital entrepreneurship. See Figure 1:

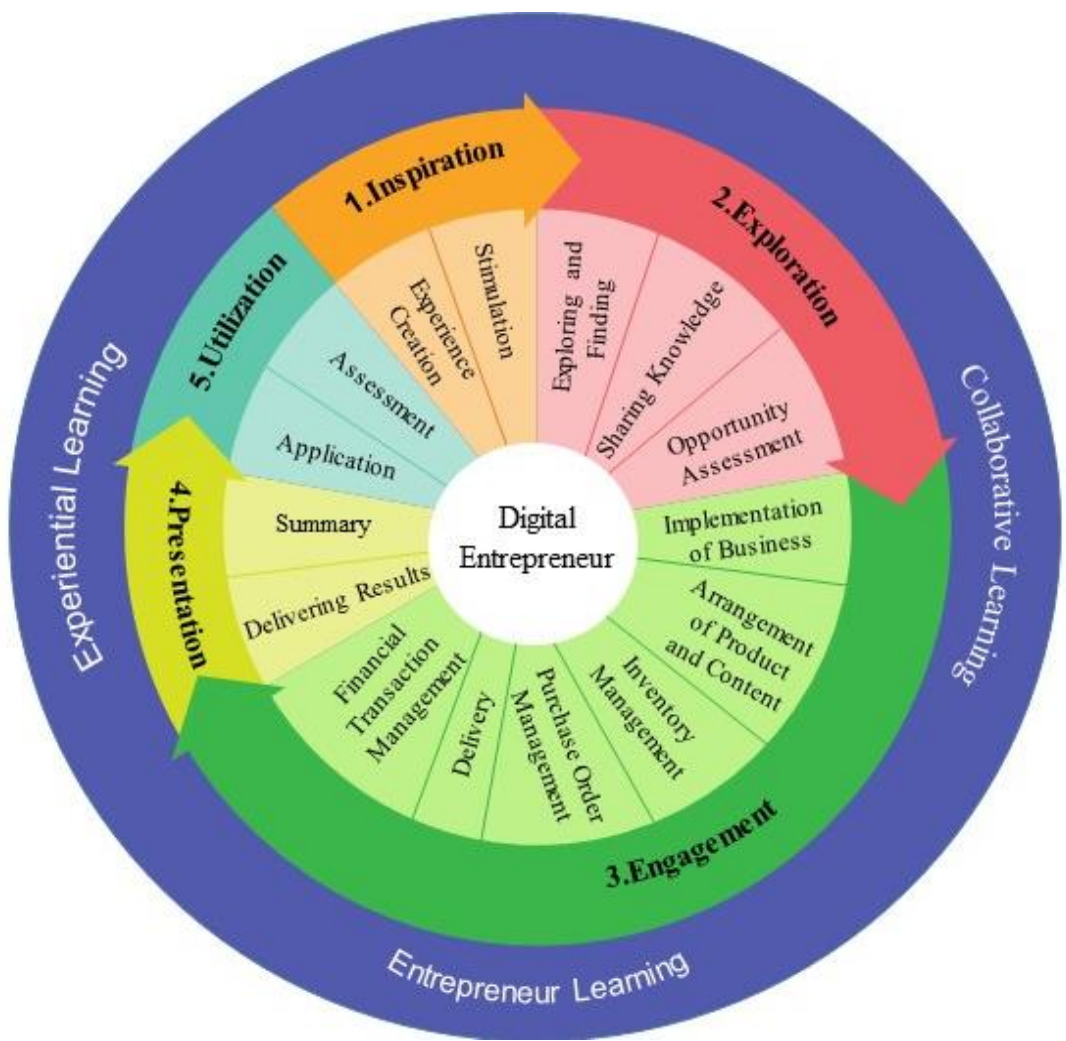

Figure 1. Collaborative Experiential Learning Process for Enhancing Digital Entrepreneurship

As shown in Figure 1, the collaborative experiential learning process for enhancing digital entrepreneurship comprises five steps and 15 procedures, as follows:

1) Inspiration: this step stimulates students' enthusiasm for learning and helps them to create a meaningful learning experience consisting of two procedures: 1. experience creation - students shape their experience according to their assigned topics and achieve the learning goal designed by their teachers, and 2. stimulation students participate in small-group activities by presenting their project topics or assignments, searching for initial information, interacting, sharing their experience and exchanging ideas. Simultaneously the teachers facilitate cooperative learning and organized activities to enhance students' knowledge using a systematic approach to develop their perceptions, awareness, and potential. This step can stimulate interest and increase engagement in teaching and learning and the start-up business.

2) Exploration: this step allows students to explore and search for information relevant to their studies. They then share the knowledge and exchange ideas among the students in the group work activities, followed by summarizing the interesting information before project/task implementation. Students use the knowledge and gain hands-on experience in doing a meaningful project which consists of three procedures: 1. exploring and finding - students explore and find concepts relating to their project or assignment, whereas team members arrange meetings, make plans, set goals for the project, engage in brainstorming activities, search for useful information/sources of funding, recruit employees to perform duties assigned by organizations and make a business plan. Teachers' duties and responsibilities are to provide students with a learning source, support their needs, and focus on reflective practice. 2. Sharing knowledge - students use experiential learning derived from their inspiration to generate a thoughtful analysis of their learning experience. This reflects the outcome of students' learning experience in keeping with their beliefs, conceptions and, opinions and encourages them to express their opinions and exchange ideas. 3. opportunity assessment - team members work together to assess business start-up-related opportunities by generating ideas and thoughtful analysis of the business plan. Students consider factors such as market needs, resources, ability, wealth, and potential development opportunities in this session.

3) Engagement: this process is about business operations and consists of six procedures: 1 . Implementation of 
business - to become a new entrepreneur in the business start-up process students in experiential learning must register as sellers. 2. Arrangement of products and content - team members create content plans and lists of products. 3. Inventory management - team members perform inventory management, including accommodating products in and out of the warehouse and customizing product details in an inventory. 4. Purchase order management - team members engage in purchase order management. The process starts when a customer makes a purchase, and then the goods are prepared for delivery. 5. Delivery - team members send out the delivery items according to the purchase order. 6. Financial transaction management - this process allows students to learn how to manage revenue and charges from selling products.

4) Presentation: this process involves presenting the overall results in front of the class and consists of two procedures: 1. a summary of students' knowledge gained from their hands-on experience and experiential learning to real-world contexts the outcomes. 2. delivering results - this process enables students to present the concepts of planning or the project/assignment process to other group members and express their opinions freely. In this section, students participate in brainstorming, generating thoughtful analysis, presenting reasons to support their ideas, and can see the reflective practice at the heart of the concept of experiential learning. However, the results derived from experiential learning must be from the construction of new knowledge, not to reveal a series of facts. Besides, teachers facilitate the presentations and check that everything goes according to the plans.

5) Utilization: students apply their knowledge and the experience they gained from their practical work to their project/task assessment as well as in other situations. This process has two procedures: 1. reflective practice on the students' own learning experience and assessment of learning outcomes, and 2. the application of knowledge gained from experience in real-world contexts.

5.2 Phase II: The Suitability Results of the Collaborative Experiential Learning Process for Enhancing Digital Entrepreneurship

Table 4. The Suitability Results of the Collaborative Experiential Learning Process for Enhancing Digital Entrepreneurship

\begin{tabular}{lccl}
\hline \multirow{2}{*}{$\begin{array}{l}\text { The Collaborative Experiential Learning Process } \\
\text { for Enhancing Digital Entrepreneurship }\end{array}$} & \multicolumn{2}{l}{ Evaluation } & Suitability \\
\cline { 2 - 3 } 1. Inspiration & $\overline{\mathbf{x}}$ & \multicolumn{1}{l}{ S.D. } & \\
1.1 Experience Creation & & & \\
1.2 Stimulation & 4.19 & 0.68 & High \\
Total & 4.43 & 0.81 & High \\
2. Exploration & 4.31 & 0.49 & High \\
2.1 Exploring and Finding & & & \\
2.2 Sharing Knowledge & 4.67 & 0.58 & Highest \\
2.3 Opportunity Assessment & 4.67 & 0.66 & Highest \\
Total & 4.29 & 0.85 & High \\
3. Engagement & 4.54 & 0.52 & Highest \\
3.1 Implementation of Business & & & \\
3.2 Arrangement of Products and Content & 4.71 & 0.56 & Highest \\
3.3 Inventory Management & 4.62 & 0.67 & Highest \\
3.4 Purchase Order Management & 4.62 & 0.59 & Highest \\
3.5 Delivery & 4.62 & 0.59 & Highest \\
3.6 Financial Transaction Management & 4.67 & 0.58 & Highest \\
Total & 4.67 & 0.58 & Highest \\
4. Presentation & 4.65 & 0.54 & Highest \\
4.1 Summary & & & \\
4.2 Delivering Results & 4.71 & 0.46 & Highest \\
Total & 4.62 & 0.59 & Highest \\
5. Utilization & 4.53 & 0.35 & Highest \\
5.1 Assessment & & & \\
5.2 Application of Knowledge & 4.48 & 0.60 & High \\
Total & 4.52 & 0.51 & Highest \\
Average Total & 4.50 & 0.50 & Highest \\
& 4.53 & 0.56 & Highest \\
\hline
\end{tabular}


According to Table 4, the suitability of the collaborative experiential learning process for enhancing digital entrepreneurship is highest. The suitability result for presentation, engagement, exploration, and utilization was also highest, while the suitability result for the inspiration process was high.

\section{Discussion}

The study of the experiential learning process, collaborative learning process, and digital entrepreneurship learning process is based on information in documents, textbooks, academic journals, and on the concepts and theories of relevant research papers. It includes an analysis and synthesis of the data using a content analysis approach conducive to developing the collaborative experiential learning process for enhancing digital entrepreneurship. This is consistent with the concept of Kolb (2014) who states that the construction of knowledge through experience or learning by doing is defined as a substantial learning experience, and is crucial for students' learning. Also consistent with the concept of Majid (2013) who says that collaborative learning is a process in which group members work towards the same goals or complete tasks that help knowledge to be constructed through mutual interaction. This is consistent with the concept of Secundo et al. (2017) who say that entrepreneurship is a process that emphasizes investigating the learning process and developing entrepreneurship which is considered a social process and a perceptual process of knowledge. Therefore, entrepreneurship is a learning process, and a theory of entrepreneurship requires a theory of learning. Entrepreneurial learning is a dynamic process that occurs during the entrepreneurial journey and a continuous learning process that allows entrepreneurs to develop and grow business. According to the suitability assessment results for the collaborative experiential learning process for enhancing digital entrepreneurship carried out by 21 experts, the overall result was the highest. When the standard deviation was considered, the data distribution occurred within a small range of values (less than 1.00). This reveals that the experts expressed the same opinions. The assessment scores were arranged in the same groups which are applied to learning and teaching management in educational institutions consistent with the concept of Desai et al. (2018) and relating to studies of the assessment of the collaborative experiential learning process to determine effective academic development as well as the success of students. This is consistent with the concept of Liu et al. (2019), who state that students engaging in an experiential learning process with a systematic and continuous approach can obtain and apply knowledge from authentic learning. Students' learning experience derives from the knowledge construction process through reflection on doing, whereas knowledge acquisition involves understanding. In this study, two groups of participants included a group gaining experience through project-based learning and a group being taught using a traditional approach. The findings suggest a statistically significant difference in the quiz scores between those students engaging in experiential learning and those being taught using a traditional approach. The results reveal that students learning through experience can develop their creativity, problem-solving, leadership, teamwork, and communication skills.

Moreover, the results from the key performance indicators used to measure students' learning achievement after the end of the semester indicate that students engaging in experiential learning can improve their test scores and gain higher scores than those taught using a traditional approach. This study's results can conclude that experiential learning can improve students' learning effectiveness and support them while studying in different fields.

This is consistent with Osipov \& Ziyatdinova (2015) concept concerning collaborative experiential learning on an engineering curriculum, which reveals there is empirical evidence to support collaborative learning. Moreover, students can develop skills in building peer relationships and trust in friends and teachers. Teamwork can lead to a positive outcome, facilitate quality analysis and creative skill development where students create and achieve their own goals. This is considered a way of finding the factors, overcoming the obstacles to success, and learning psychology principles to encourage and enhance professional skills. This is consistent with the concept of Laal et al. (2013), who states that collaborative learning is an educational approach that allows students to work on a task in pairs or small groups and enables them to generate thoughtful analysis, exchange ideas, and discuss issues among themselves. Each member is responsible for their role and peer assessment and feedback about each other's work. Feedback given to members and groups is used to identify those who may need additional support. Digital entrepreneurship learning is an essential process for digital entrepreneurs. It is consistent with the concept of Jelonek (2015), who says that digital entrepreneurship is a subcategory of entrepreneurship that focuses on the transformation of business activities or digital transformation with virtualization for the whole or some part of the existing business activities/process. Today, the internet is essential for developing the business environment where e-commerce is replacing traditional commerce. It is essential that the entrepreneur becomes a digital entrepreneur, consistent with Kraus et al. (2018) concept. They 
state that the entrepreneur leverages technology in novel ways to create and do business in the digital era and ultimately to create opportunities for people. Today, digital business is having an impact on society. Digital entrepreneurship is 'a subcategory of entrepreneurship in which some or all of what would be physical in a traditional organization has been digitized'. Thus, traditional entrepreneurs should make an effort to transform the existing products, services, and business into a digital model.

\section{Conclusions}

According to the research findings regarding the synthesis of the collaborative learning, experiential learning, and digital entrepreneurship processes in which the data is derived from theory, documents, and other related research, the collaborative experiential learning process of digital entrepreneurship consists of five steps: 1) Inspiration 2) Exploration 3) Engagement 4) Presentation and 5) Utilization. The evaluations of the experts indicate that the collaborative experiential learning process of digital entrepreneurship suitability was at the highest level.

\section{Acknowledgments}

We would like to express my sincere thanks to the special expertise and another person for suggestions and all their help for my research, including King Mongkut's University of Technology North Bangkok, Thailand (KMUTNB).

\section{References}

Coleman, D., \& Levine, S. (2008). Collaboration 2.0: Technology and Best Practices for Successful Collaboration in a Web 2.0 World. Happy About.

Cooper, L., \& Burford, S. (2010). Collaborative Learning: Using Group Work Concepts for Online Teaching. In Martin, J., \& Hawkins, L. (Ed.), Information Communication Technologies for Human Services Education and Delivery: Concepts and Cases (pp. 37-52). IGI Global. https://doi.org/10.4018/978-1-60566-735-5.ch003

Desai, P., Bhandiwad, A., \& Shettar, A. (2018). Impact of Experiential Learning on students' success in Undergraduate Engineering. In IEEE 18th Intrenational conference on Advanced Learning Technologies (ICALT) (pp.46-50). IEEE. https://doi.org/10.1109/ICALT.2018.00018

Dewey, J. (1986). Experience and education. The education forum (pp.241-252). Spring.

Gerlach, J. M. (1994). Is This Collaboration? Jossey-Bass Publishing.

Gokhale, A. A. (1995). Collaborative learning enhances critical thinking. Journal of Technology Education. https://doi.org/10.21061/jte.v7i1.a.2

Haynes, C. (2007). Experiential learning: Learning by doing: 5-step experiential learning cycle definitions. University of California Davis.

Holcomb, S. (2016). Entrepreneurial Process. In S. Holcomb (Ed.), HCS 567: marketing management (pp.1-5). University of Phoenix. Honey, P., \& Mumford, A. (1992). The Manual of Learning Styles (3rd ed.). Peter Honey.

Honey, P., \& Mumford, A. (1992). The manual of learning styles (3rd ed.). Peter Honey.

Institute for Experiential Learning. (2016). What Is Experiential Learning. Retrieved from https://experientiallearninginstitute.org/resources/what-is-experiential-learning

JD Central Seller Help Center. (2019). Sale on JD Central. Retrieved from https://helpcenter.jd.co.th/hot/ index

Jelonek, D. (2015). The Role of Open Innovations in the Development of e-Entrepreneurship. Procedia Computer Science, 65, 1013-1022. https://doi.org/10.1016/j.procs.2015.09.058

Johnson, R. T., \& Johnson, D. W. (1986). Cooperative learning in the science classroom. Science and children, 24(2), 31-32.

Kang, Y. C., \& Chen, J. Y. (2016). Applying Kano Model to Evaluate the Quality for Mobile Experiential Learning Model. IN 2016 International Conference on Applied System Innovation (ICASI) (pp.1-3). IEEE. https://doi.org/10.1109/ICASI.2016.7539882

Kolb, D. A. (2014). Experiential learning: Experience as the source of learning and development. FT press.

Koschmann, T., Kelson, A. C., Feltovich, P. J., \& Barrows, H. S. (1996). Computer-supported problem-based 
learning: A principled approach to the use of computers in collaborative learning. CSCL: Theory and practice of an emerging paradigm, 83-124.

Kraus, S., Palmer, C., Kailer, N., Kallinger, F. L., \& Spitzer, J. (2018). Digital entrepreneurship: a research agenda on new business models for the twenty-first century. International Journal of Entrepreneurial Behavior \& Research, 25(2), 353-375. https://doi.org/10.1108/IJEBR-06-2018-0425

Kuandee, W., Nilsook, P., \& Wannapiroon, P. (2019). Asset Supply Chain Management System-based IoT Technology for Higher Education Institutions. International Journal of Online and Biomedical Engineering, 15(3), 4-20. https://doi.org/10.3991/ijoe.v15i03.8533

Laal, M., Geranpaye, L., \& Daemi, M. (2013). Individual accountability in collaborative learning. Procedia Social and Behavioral Sciences, 93, 286-289. https://doi.org/10.1016/j.sbspro.2013.09.191

Laal, M., \& Laal, M. (2012). Collaborative learning: what is it?. Procedia - Social and Behavioral Sciences, 31, 491-495. https://doi.org/10.1016/j.sbspro.2011.12.092

Lazada University. (2018). Traning on how to use seller center. Retrieved from https://cdn.thaitrade.com/stocks/extra/0015d7.pdf

Liu, Y. C., Lu, S. J., Kao, C. Y., Chung, L., \& Tan, K. H. (2019). Comparison of AR and physical experiential learning environment in supporting product innovation. In 2019 International Journal of Engineering Business Management, 11, 1-10. https://doi.org/10.1177/1847979019839578

Madani, R. A. (2019). Analysis of Educational Quality, a Goal of Education for All Policy. Higher Education Studies, 9(1). 102-109. https://doi.org/10.5539/hes.v9n1p100

Majid, O. B., Hilmi, M. F., Rashid, N. A., Syed-Mohammad, S. M., Malim, N., \& Zainol, Z. (2013). Collaborative Learning Environment with Think-Pair-Share Method and Learning Tools for Learning Arabic Online. In 2013 Taibah University International Conference on Advances in Information Technology for the Holy Quran and Its Sciences (pp. 77-82). IEEE. https://doi.org/10.1109/NOORIC.2013.27

Osipov, P. N., \& Ziyatdinova, J. N. (2015). Collaborative learning: Pluses and problems. In 2015 International Conference on Interactive Collaborative Learning (ICL) (pp. 361-364). IEEE. https://doi.org/10.1109/ICL. 2015.7318054

Panitz, T. (1999). Collaborative Versus Cooperative Learning: Comparing the Two Definitions Helps Understand the nature of Interactive learning. Cooperative Learning and College Teaching.

Pfeiffer, J. W., \& Jones, J. E. (1983). Experiential Learning Model. John Wiley \& Sons.

Politis, D. (2005). The process of entrepreneurial learning: A conceptual framework. Entrepreneurship theory and practice, 29(4), 399-424.

Ravensbergen, R. (2015). Buliding E-Commerce Solutions with WooCommerce. Packt Publishing Ltd.

Ravensbergen, R. and Schoneville, S. (2013). Magento Beginner's Guide. Packt Publishing Ltd.

Reid, J. A., Forrestal, P., \& Cook, J. (1989). Small Group Learning in the Classroom. Chalkface Press.

Ruangvanich, S., \& Nilsook, P. (2018). Personality Learning Analytics System in Intelligent Virtual Learning

Environment. In Proceedings of the 6th International Conference on Information Technology: IoT and Smart City (pp. 245-250). https://doi.org/10.1145/3301551.3301582

Secundo, G., Del Vecchio, P., Schiuma, G., \& Passiante, G. (2017). Activating entrepreneurial learning processes for transforming university students' idea into entrepreneurial practices. International Journal of Entrepreneurial Behavior \& Research, 23(3), 465-485. https://doi.org/10.1108/IJEBR-12-2015-0315

Shiralkar, S. W. (2016). IT Through Experiential Learning: Learn, deploy and adopt IT through gamification. Apress. https://doi.org/10.1007/978-1-4842-2421-2

Shopee Seller Education Hub (2020). The Article. Retrieved from https://seller.shopee.com.my/edu/category? sub_cat_id=591

Stacey, E. (1999). Collaborative learning in an online environment. Journal of Distance Education, 14(2), 14-33.

Techakosit, S., \& Nilsook, P. (2016). The Learning Process of Scientific Imagineering through AR in Order to Enhance STEM Literacy. International Journal of Emerging Technologies in Learning, 11(7). https://doi.org/10.3991/ijet.v11i07.5357

Thanachawengsakul, N., Wannapiroon, P., \& Nilsook, P. (2019). The Knowledge Repository Management 
System Architecture of Digital Knowledge Engineering using Machine Learning to Promote Software Engineering Competencies. International Journal of Emerging Technologies in Learning, 14(12), 42-56. https://doi.org/10.3991/ijet.v14i12.10444

van Laar, E., van Deursen, A. J., van Dijk, J. A., \& de Haan, J. (2018). 21st-century digital skills instrument aimed at working professionals: Conceptual development and empirical validation. Telematics and Informatics, 35(8), 2184-2200. https://doi.org/10.1016/j.tele.2018.08.006

van Welsum, D. (2016). Enabling digital entrepreneurs. World Development Report. Retrieved from http://documents.worldbank.org/curated/en/2016/02/25851780/world-development-report-2016-digital-divi dends-enabling-digital-entrepreneurs

van Zyl, C. (2018). The Entrepreneurial Process and Legal Issues. In The Emerald Handbook of Entrepreneurship in Tourism, Travel and Hospitality. Emerald Publishing Limited. https://doi.org/10.1108/ 978-1-78743-529-220181031

Xiu-qing, P., \& Li, C. (2013). The relationship between entrepreneurial learning and entrepreneurial knowledge. In 2013 International conference on management science and engineering 20th annual conference proceedings (pp. 1314-1319). IEEE. https://doi.org/10.1109/ICMSE.2013.6586442

Zhao, F., \& Collier, A. (2016). Digital Entrepreneurship: Research and Practice. In: 9th Annual Conference of the EuroMed Academy of Business (pp.2173-2182).

\section{Copyrights}

Copyright for this article is retained by the author(s), with first publication rights granted to the journal.

This is an open-access article distributed under the terms and conditions of the Creative Commons Attribution license (http://creativecommons.org/licenses/by/4.0/). 